\title{
High-temperature processing of municipal solid waste
}

\author{
Olga Barysheva*, Yuri Khabibullin and Aida Mukhametzianova \\ Kazan State University of Architecture and Engineering, Kazan, Russian Federation
}

\begin{abstract}
At present, processing and recycling of municipal solid waste (MSW) has become more relevant in our country and the world at large. This problem concerns large towns and cities, where every year millions of tons of all kinds of fractions of household waste are produced. Disposal or recycling of solid waste is an environmental issue, but it is associated with the solution of complex technical, energy and economic challenges. The purpose of this study is to identify the advantages and disadvantages of modern methods of processing and disposal of MSW with the prospect of developing and creating a device for recycling MSW taking into account modern approaches to energy saving and environmental protection. The main results of the study are to create a simple, reliable and technically sound method of MSW disposal to obtain additional energy. The significance of the results obtained for the construction industry is the design of a device for the disposal of solid waste with the production of solid combustion products and further their use as building materials and products for various purposes. Because of the technological process of MSW processing, it becomes possible to generate some returns through use of resulting thermal energy for electricity production.
\end{abstract}

\section{Introduction}

The increasing volume of municipal solid waste demands acceptance of urgent measures for their removal and elimination from territories of settlements. Each resident on average throws out $400-500 \mathrm{~kg}$ of garbage a year [1-4].

Processing of MSW are the complex problem demanding big money and new technologies. At a delay of removal of MSW from territories of the cities and in, features, from megalopolises the emergence of global epidemics is possible [5-9].

The main problem for the next years is search of effective ways of processing of MSW. Today burial of MSW for the present is the main way of their utilization. At many enterprises and institutions, old technologies prevail and therefore in settlements the waste having the increased danger to the population collects. Burial of this waste does not solve a problem of their neutralization; it only shifts the solution of this problem on the near future [10-14].

The approaches to utilization of MSW existing now is burial, transformation to biogas, processing in organic fertilizer are not always acceptable as they, as a rule, are not followed at least by preliminary sorting all of the increasing garbage stream. Unfortunately, sorting of garbage is very expensive an action and, in modern economic realities is unrealizable.

Therefore, now the most expedient method of utilization of MSW is their burning with preliminary sorting just before their destruction [15].

MSW consist of fractions, various on heat of combustion, and average heat of combustion depends on external parameters are humidity, temperature, pressure. Average heat of combustion of MSW makes about 8000 $\mathrm{kJ} / \mathrm{kg}$. This marked-out thermal energy has to be surely used therefore already in the near future burning with effective use of the marked-out energy will be the main method of processing of MSW.

Already in the nearest future waste incineration, installations with development of additional amount of thermal and electric energy will successfully compete with the traditional systems of classical power [16-20].

\section{Methods of Utilization of MSW}

A promising method for processing MSW is separation and recycling of all waste components and their subsequent use in the national economy. There are two approaches for the implementation of this plan [1].

The first approach at the inlet of this complex should be provided pad unparsed weight of solid waste. Downstream but this approach is considered ideal in the present conditions cannot be realized $[2,3]$.

Certainly, it is possible to divide the waste stream with the help of robotics, but such a process would not pay off and therefore unacceptable.

The second approach is most often used in developed countries. Here, in residential areas and tanks are installed with special mark different colors to plastics, paper, glass, metal, organic, etc. Ideally, the population or employees of institutions that produce waste should share the waste.

The average composition of MSW [4-7] presented in Table 1.

\footnotetext{
* Corresponding author: obbars@gmail.com
} 
Table 1. The average composition of MSW.

\begin{tabular}{|c|c|}
\hline Name & Composition, $\%$ \\
\hline $\begin{array}{c}\text { Polymers: PVC, polyethylene, } \\
\text { polypropylene }\end{array}$ & 50 \\
\hline Food waste & 25 \\
\hline Paper, wood & 10 \\
\hline Rubber, metal, textiles & $15-20$ \\
\hline
\end{tabular}

Among waste management methods, currently first place belongs to landfill, which take out the main part of the waste. However, the waste of their toxicological effects are acutely and extremely dangerous. Therefore, the site where they are stored, causing enormous damage to the environment, namely, the result is severe contamination as the ground surface, and ground to a depth of 20 meters, as well as underground water [8-11].

In some European countries polygons used for converting biogas which is formed during the rotting waste in renewable energy sources. MSW conversion into biogas stage are shown in Table 2 .

The heat of combustion of biogas enables its application in the energy sector. When the expansion of one ton of MSW is released $\sim 260 \mathrm{~m}^{3}$ of biogas. As a result, decomposition of waste produced combustible gas mixture consisting of approximately $60 \% \mathrm{CH}_{4}$ methane, $35 \% \mathrm{CO}_{2}$ carbon dioxide and 5\% nitrogen $\mathrm{N}_{2}$.

Particularly dangerous from an environmental point of view are unorganized dumps, because in which the combustible gas mixture enters the atmosphere from the soil displacing oxygen $\mathrm{O}_{2}$, and prevents the growth of plants. Unorganized dump a fire.

To implement the second method for processing MSW at a selected site must dig a ditch. Further, the pit must be isolated from soil and lay pipelines for output of biogas from garbage array for its further use in the heat (heating, power generation).

A third approach is the processing of solid waste into organic fertilizer (compost).

The process of neutralization and refining is due to self-heating of MSW, resulting in the development of aerobic thermophilic microorganisms at a sufficient amount of oxygen $\mathrm{O}_{2}$.

In the course of chemical and biological reactions of solid waste to the self-heating temperature $T=60 \ldots 70^{\circ} \mathrm{C}$. This temperature is detrimental for pathogenic bacteria, thereby enabling disposal. With stirring, the best material obtained by the contact between the organic matter and microorganisms. Complex organic compounds are decomposed to form shapes, which are easily assimilated by plants (compost).

Half reduce further enzymatic biodegradable material mass, and the solid obtained a stable product. However, direct composting solid waste is impractical because derived fertilizers contaminated with heavy metals and glass (electronic waste - computers, televisions, mobile phones, etc., light bulbs, used galvanic cells). This requires careful sorting of waste, which is not always economically feasible.

The fourth approach is the burning of MSW. In most cases, it is the most suitable method of solid waste disposal.

Waste consist of different character calorific value and different-sized particles, the average calorific value of which is dependent on external parameters: temperature, pressure, humidity. Average heat of combustion of MSW $\sim 8000 \mathrm{~kJ} / \mathrm{kg}$ [12-16]. The combustion of MSW consumes a large amount of oxygen $\mathrm{O}_{2}$, which increases considerably with increasing content of the waste plastic materials. Advantages and disadvantages of MSW incineration in Table 3 are shown.

Table 3. Thermal utilization of solid waste.

\begin{tabular}{|c|c|}
\hline $\begin{array}{c}\text { Advantages MSW } \\
\text { incineration }\end{array}$ & $\begin{array}{c}\text { Disadvantages MSW } \\
\text { incineration }\end{array}$ \\
\hline $\begin{array}{c}\text { Reducing the volume of } \\
\text { solid waste by more than } \\
\text { an order of magnitude }\end{array}$ & $\begin{array}{c}\text { Soil contamination danger } \\
\text { emissions }\end{array}$ \\
\hline Reliable disposal & $\begin{array}{c}\text { Danger of harmful } \\
\text { atmospheric pollution } \\
\text { emissions }\end{array}$ \\
\hline $\begin{array}{c}\text { Reducing the risk of } \\
\text { environmental pollution }\end{array}$ & $\begin{array}{c}\text { A significant (15-25\%) share } \\
\text { of the resulting slag }\end{array}$ \\
\hline $\begin{array}{c}\text { The possibility of } \\
\text { additional energy }\end{array}$ & $\begin{array}{c}\text { Destruction of valuable } \\
\text { components of MSW }\end{array}$ \\
\hline
\end{tabular}

It should be noted that when burning MSW released into the atmosphere chloride and hydrogen fluoride, sulfur dioxide, nitrogen oxides, and metals and their compounds, mainly aerosol form $[17,18]$. Incineration of waste containing synthetic polymeric materials formed

Table 2. MSW conversion step into biogas.

\begin{tabular}{|c|c|c|}
\hline Name & Durations & Result \\
\hline I - aerobic stage & $\begin{array}{c}\text { From several weeks to } \\
\text { several months }\end{array}$ & Activated activity of bacteria that consume oxygen \\
\hline II - anaerobic stage & Several months & $\begin{array}{l}\text { It begins to show the activity of microorganisms that exist in an } \\
\text { environment with a minimal amount of oxygen changes the } \\
\text { physical and chemical composition of solid waste and the formation } \\
\text { of organic acids }\end{array}$ \\
\hline $\begin{array}{l}\text { III - anaerobic } \\
\text { unstable methane } \\
\text { phase }\end{array}$ & More than one year & Activated by bacterial activity, methane $\mathrm{CH}_{4}$ \\
\hline $\begin{array}{c}\text { IV - Anaerobic } \\
\text { stable methane phase }\end{array}$ & Decades & $\begin{array}{l}\text { In the process of entering, the microorganisms decompose the } \\
\text { organic component of MSW without air access to such components } \\
\text { as methane - } \mathrm{CH}_{4} \text {, carbon dioxide - } \mathrm{CO}_{2} \text {, water - } \mathrm{H}_{2} \mathrm{O}\end{array}$ \\
\hline
\end{tabular}


dioxins and furans. Dioxins is the group of substances, molecules that constitute the basis of hexagonal carbon rings. If they have no chlorine atoms, these toxic substances is not more than gasoline, but the substitution of hydrogen atoms in the rings of chlorine atoms formed dangerous dioxins is only about twenty compounds of varying degrees of toxicity [19].

Group furans less toxic than dioxin group, but also those, and others are carcinogenic. There are plenty of sources of uncontrolled emissions of dioxins and furans the temperature of combustion is low $\left(T<600^{\circ} \mathrm{C}\right)$. When this mode is formed in ten times more dioxins and furans than in incineration plants, where a high-temperature process is used (more than $1000^{\circ} \mathrm{C}$ ).

Dioxins is toxic and carcinogenic substances synthesized by man, so pre-sorting of waste prior to incineration is needed. One of the species is a pyrolysis combustion process is a thermal decomposition of solid waste without air.

Because of this process produced combustible gas, liquid and solid products carbonaceous residue.

Depending on the temperature of pyrolysis distinguish the following types: low-temperature pyrolysis $\left(T<500{ }^{\circ} \mathrm{C}\right)$, wherein the yield of liquid products and solid residue is maximal and minimal yield of fuel gas; medium temperature pyrolysis $\left(T=500 \ldots 1000{ }^{\circ} \mathrm{C}\right)$. With such hot pyrolysis gas yield increases, and the yield of liquid products and solid residue decreases; high-temperature pyrolysis (more than $1000{ }^{\circ} \mathrm{C}$ ), whereby the yield of liquid products and solid residue is minimal, and the output of fuel gas is maximal. Pyrolysis provides an opportunity not only to dispose of household waste, but also to receive valuable hydrocarbons of petroleum series. Consequently, reduced processing costs of solid waste.

By pyrolysis disadvantages: complicated construction and high cost ovens; great staff; incomplete disintegration of dioxins at the end of the process; Heavy metals do not melt and precipitate together with the sludge.

Currently, the emphasis is on technology, not only for MSW incinerators, but also for the transformation from resulting heat energy.

It is believed [20] that in the near future combustion with generation of electricity and heat is the main method of processing waste. In the future, waste incineration power plants will be included in the integrated waste management system, together with enterprises on recycling and reuse of some materials (metal, glass, plastic, paper, etc.)

Along with this improvement requires the resulting flue gas cleaning methods. Various schemes MSW incineration. The main disadvantage of these devices is the low degree of purification of produced harmful emissions, and low economic efficiency of the process.

\subsection{Description installation with improved emission purification system}

An installation with improved emission purification system in order to increase the economic efficiency of the process. Installation is presented in fig. 1.

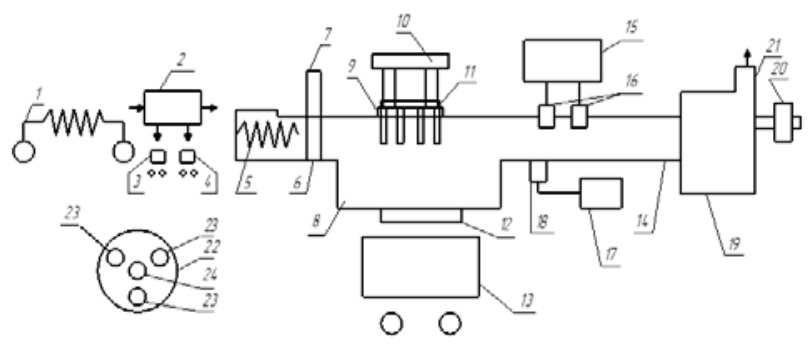

Fig. 1. Apparatus for high temperature treatment of solid waste: 1 - conveyor, 2 - separator of metal, 3,4 - containers, 5 - screw, 6 - loading hatch, 7- gate, 8 - combustion chamber, 9 - block of electrodes, 10 - three-phase power supply, 11 arch activator, 12 - hatch, 13 - container for firm products of processing, 14 - afterburner, 15 - high-voltage power supply, 16 - spark plugs, 17 - ozonizer, 18 - nozzle for ozone supply, 19 - copper utilizer, 20 - turbo generator, 21 - vent pipe, 22 unit housing of electrodes, 23 - electrodes, 24 - central electrode.

Installation for high-temperature processing of solid waste is as follows.

Waste on the conveyor 1 pass through the separator of metal 2. It ferrous metal is separated and falls into the containers 3 and 4 . The waste separated by a metal screw 5 through the loading hatch 6 overlap flap 7. In the furnace 8 disposed electrode unit 9 , which supplied with power from a three-phase power source 10 . The electrode assembly 9 itself includes a cylindrical body 22, electrode 23 and central electrode 24 .

Each of the electrodes 23 disposed along the periphery of the housing 22, the block electrodes of cylindrical shape connected to a power supply phase 10 and central electrode 24 is connected to the neutral conductor has a length of one diameter greater than the remaining electrodes, thereby increasing the combustion zone of electric arcs. All electrodes have the same diameter.

When using a three-phase alternating electric current is observed effects of electric arcs pressure combustible wastes at temperatures $T=1500 \ldots 1800{ }^{\circ} \mathrm{C}$, causes rotation and vigorous stirring melt able mineral components, more complete reaction and the release of mineral residue from the gases.

The use of a three-phase arc instead of a singlephase power provides savings of up to 35-40\%. Excitation electric arcs produced by the activator 11 .

Unloading of solid combustion products produced through the manhole 12 into the container 13 . The solid combustion products can be successfully processed in different directions. Of the ash, using plasma technology produces artificial sand paving filling. Also, use ash can to produce ceramic and concrete products for construction application.

The effluents from the combustion chamber 8 gaseous products enter the afterburner 14 , where they are 
neutralized and ignition of spark plug 16, fed by the high voltage unit 15 .

To intensify the neutralization process gases in the afterburner 14 from the ozonizer 17 through the nozzle 18 is supplied ozone. Neutralized gaseous combustion products enter the heat recovery boiler 19 . The resulting vapor therein is sent to a turbine generator 20 to produce electricity. The neutralized and cooled product gases enter the atmosphere through a stack 21.

\section{Results and Discussion}

Installation took out the patent for an invention. Also allows utilizing municipal solid waste with the minimum emission of toxic substances. This installation has no analogs.

During the operation of similar units, certain requirements to composition of initial raw materials are necessary and there is a rigid dependence of technological processes on quality of MSW.

In addition, essential lack of these devices is the low efficiency of processing of municipal solid waste. Besides, implementation of ways of processing of MSW at temperatures below $1100{ }^{\circ} \mathrm{C}$ and duration of stay of products of decomposition of MSW in the combustion chamber leads less than 2 sec. to formation of products of incomplete combustion and super toxic and thermodynamic steady dioxins and furans. Their processing is necessary for elimination of abovementioned substances at temperatures of $T=1500 \ldots 1800^{\circ} \mathrm{C}$, as it is reached in the offered installation.

The numerical experiment of computer model of this installation was made. Results of the computing experiment, which show changes of mole dole of chlorobenzene depending on temperature and a mass fraction of the products after thermal utilization MSW, are given in fig. 2 .

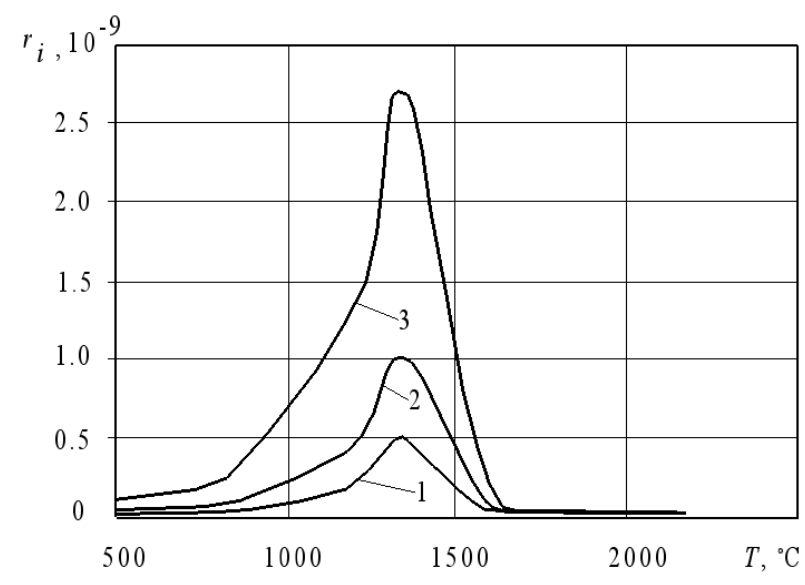

Fig. 2. Change of mole dole $r$ of chlorobenzene depending on temperature and a mass fraction $g$ of the products after thermal utilization of MSW: $1-g=0.03$; $2-g=0.04$; $3-g=0.05$.

It is visible from fig. 2 that the maximum concentration of chlorobenzene as harbinger of dioxins is at temperatures of $T=1300 \ldots 1350{ }^{\circ} \mathrm{C}$. Further, concentration decreases to zero values. Thus, chlorobenzene burns down.

For better neutralization at combustion of municipal solid waste of the formed dioxins and furans, their neutralization in the afterburner and in the environment of gaseous ozone is used.

In comparison with the system of flowing nonstationary reactors [21] this installation gives vent smaller harbingers of dioxins in $~ 100$ times under the same physical conditions.

The neutralized gaseous combustion products come to the exhaust heat boiler producing steam, which goes to the turbine generator for production of additional quantity of the electric power that gives considerable economic effect.

Use of a three-phase electric arc instead of singlephase gives economy of electrical energy to $40 \%$. Thus, a gaseous component which as a rule, contains dangerous and toxic substances, including compounds of chlorine and fluorine, dioxins, furans, hydrocarbons and others are exposed to chemical heat treatment.

At the same time, there is their destruction thanks to heating to high temperature at which their stability sharply goes down, and to course of chemical reactions with formation of new non-toxic or much less toxic substances.

\section{Conclusions}

Solid waste obtained when burning MSW can be fully disposed of, inter alia, are proposed for inclusion as additives for street paving and ceramic and concrete products. It is also possible to obtain additional revenue by converting the resulting heat into electricity. In the developed device obtained patent [22].

Solid combustion products can be used in the road and construction industries.

\section{References}

1. F. Du, K. Wang. Process Safety and Environmental Protection. Unstable failure of gas-bearing coal-rock combination bodies: Insights from physical experiments and numerical simulations. 129, pp. 264-291 (2019).

2. P. Chaudhari, B. Ravi, P. Bagaria and C. Mashuga. Process Safety and Environmental Protection. Improved partial inerting MIE test method for combustible dusts and its CFD validation. 122, pp. 192-200. (2019).

3. A. Shehzad, M.J.K. Bashir, S. Sethupathi and J.-W. Lim. Process Safety and Environmental Protection. An overview of heavily polluted landfill leachate treatment using food waste as an alternative and renewable source of activated carbon. 98, pp. 309-319 (2015).

4. J.V. Jayarama Krishna, O.P. Korobeinichev, R. Vinu. Process Safety and Environmental Protection. Isothermal fast pyrolysis kinetics of synthetic polymers using analytical Pyroprobe. 139, pp. 48-58 (2019).

5. D. Li, Hai-Qun Xu, Long Jiao, Hai-Long Jiang. Journal of the Energy Institute. Metal-organic frameworks for catalysis: State of the art, challenges, and opportunities. 1, Article 100005 (2019). 
6. S.Zhu, Q.Lyu, Jianguo Zhu, C. Liang. EnergyChem. The roles of the low molecular weight compounds in the low-temperature pyrolysis of low-rank coal. 92, pp. 203209 (2019).

7. H. Wu, J.Zuo, H. Yuan, G. Zillante, J.Wang. Resources, Conservation and Recycling. A review of performance assessment methods for construction and demolition waste management. 150, Article 104407 (2019).

8. K. Barbakadze, W. Brostow, G. Granowski, N. Hnatchuk. Resources, Conservation and Recycling. Separation of metal and plastic wastes from wire and cable manufacturing for effective recycling. 139, pp. 251-258 (2018).

9. L. M.Sarmiento, K. A. Clavier, J. M. Paris, C. C. Ferraro, T. G. Townsend. Resources, Conservation and Recycling. Critical examination of recycled municipal solid waste

incineration ash as a mineral source for portland cement manufacture - A case study. 148, pp. 1-10 (2019).

10. S. O. Ajayi, L. O. Oyedele, M.Bilal, O. O. Akinade, K. O. Kadiri. Resources, Conservation and Recycling. Waste effectiveness of the construction industry: Understanding the impediments and requisites for improvements. 102, pp. 101-112 (2015).

11. Y.Liu, P. Xing, J. Liu. Resources, Conservation and Recycling. Environmental performance evaluation of different municipal solid waste management scenarios in China. 125, pp. 98-106 (2017).

12. I. Muise, M. Adams, R. Cote, G.W. Price. Resources, Conservation and Recycling. Attitudes to the recovery and recycling of agricultural plastics waste: A case study of Nova Scotia, Canada. 109, pp. 137-145 (2016).

13. A. J. Ridout, M. Carrier, J. Görgens. Journal of Analytical and Applied Pyrolysis. Fast pyrolysis of low and high ash paper waste sludge: Influence of reactor temperature and pellet size.111, pp. 64-75 (2015).

14. J.Xiao, F. Li, Q. Zhong, J. Huang, Y. Zhang. Journal of Analytical and Applied Pyrolysis. Effect of hightemperature pyrolysis on the structure and properties of coal and petroleum coke. 117, pp. 64-71 (2016).

15. S.Wu, S. Huang, Y. Wu, J. Gao. Journal of the Energy Institute. Characteristics and catalytic actions of inorganic constituents from entrained-flow coal gasification slag. 88, pp. 93-103 (2015).

16. G. Chen, X. Ma, M. Lin, X. Peng, Z. Yu. Journal of the Energy Institute. Pollutant emission characteristics and interaction during low-temperature oxidation of blended coal. 89 pp. 40-47 (2016).

17. K. Singh, J. Zondlo. Journal of the Energy Institute. Co-processing coal and torrefied biomass during direct liquefaction. 90, pp. 497-504 (2017).

18. Keyoon Duanguppama, Nuchida Suwapaet, Adisak Pattiya. Journal of Analytical and Applied Pyrolysis. Fast pyrolysis of contaminated sawdust in a circulating fluidised bed reactor. 118, pp. 63-74 (2016).

19. R. Miandad, M.A. Barakat, Asad S. Aburiazaiza, M. Rehan, A.S. Nizami. Process Safety and Environmental Protection. Catalytic pyrolysis of plastic waste: A review. 102, pp. 822-838 (2016).

20. X. Wang, Z. Hu, G. Wang, X. Luo, H. Tan. Journal of the Energy Institute. Influence of coal co-firing on the particulate matter formation during pulverized biomass combustion. 92, pp. 450-458 (2019).

21. V.E. Alemasov, A.F. Dregalin, A.S. Cherenkov. Bases of the theory of physical and chemical processes in heat engines and power stations. - M.: Chemistry, 2000. - 520 p.

22. Installation for high-temperature processing of municipal solid waste: patent 2669316 of the Rus. Federation. № 2017134227; decl. 02.10.2017; publ. 10.10.2018. 